\title{
Chemoprevention of prostate cancer in men with high-grade prostatic intraepithelial neoplasia (HGPIN): a systematic review and adjusted indirect treatment comparison
}

\author{
Kang Cui ${ }^{1, *}$, Xiangnan $\mathrm{Li}^{2, *}$, Yabing $\mathrm{Du}^{1, *}{ }^{*}$, Xiance Tang ${ }^{3}$, Seiji Arai ${ }^{4,5}$, Yiwei Geng ${ }^{1}$, \\ Ying $X^{1}{ }^{1}$, Han $X_{u^{6}}$, Yue Zhou ${ }^{7}$, Wang $M^{1}$ and Tengfei Zhang ${ }^{1}$ \\ ${ }^{1}$ Department of Oncology, The First Affiliated Hospital of Zhengzhou University, Zhengzhou, Henan, China \\ 2 Department of Thoracic Surgery, The First Affiliated Hospital of Zhengzhou University, Zhengzhou, Henan, China \\ ${ }^{3}$ Department of Medical Affairs, Henan Cancer Hospital, Affiliated Cancer Hospital of Zhengzhou University, Zhengzhou, \\ Henan, China \\ ${ }^{4}$ Department of Hematology and Oncology, Beth Israel Deaconess Medical Center, Harvard Medical School, Boston, \\ Massachusetts, United States \\ ${ }^{5}$ Department of Urology, Gunma University Graduate School of Medicine, Maebashi, Japan \\ ${ }^{6}$ Department of Breast Surgery, The First Affiliated Hospital of Zhengzhou University, Zhengzhou, Henan, China \\ 7 Deparmtent of B-Ultrasound, The First Affiliated Hospital of Zhengzhou University, Zhengzhou, Henan, China \\ * These authors have contributed equally to this work \\ Correspondence to: Tengfei Zhang, email: biojacob@gmail.com \\ Wang Ma, email: doctocrmawang@126.com \\ Keywords: HGPIN, prostate cancer, chemoprevention, adjusted indirect meta-analysis, green tea catechins \\ Received: February 12, $2017 \quad$ Accepted: March 06, $2017 \quad$ Published: March 15, 2017 \\ Copyright: Cui et al. This is an open-access article distributed under the terms of the Creative Commons Attribution License (CC-BY), which \\ permits unrestricted use, distribution, and reproduction in any medium, provided the original author and source are credited.
}

\section{ABSTRACT}

Background: High-grade prostatic intraepithelial neoplasia (HGPIN) is the precursor or premalignant form of prostate cancer. At least $30 \%$ patients with a confirmed HGPIN will develop prostate cancer within 1 year after repeated biopsy. HGPIN patients are the appropriate at-risk population for chemoprevention strategies investigation against prostate cancer. However the commonly used chemoprevention agents that targeted on hormonal imbalance or lifestyle-related factors showed varied results in HGPIN patients.

Methods: Literature searches were conducted in PubMed, EMBASE and Cochrane library according to Cochrane guidelines before January $31^{\text {st }}, 2017$. Direct metaanalysis were performed to summarize the efficacy of candidate chemopreventative agents Dutasteride, Flutamide, Toremifene, Selenium, Green tea components, Lycopene and natural food products combination. Adjusted indirect meta-analyses were employed to compare the relative efficacy of these candidate chemoprevention agents head-to-head.

Results: The overall incidence of prostate cancer in HGPIN was slightly decreased by chemoprevention agents $(25.7 \%$ vs $31.5 \%, R R=0.92,95 \%$ CI: $0.83-$ $1.03, P=0.183)$, with minor heterogeneity $\left(I^{2}=22.3 \%, \chi^{2}=15.08, P=0.237\right)$, but without statistical significance. Subgroup analysis showed that green tea catechins significantly decreased prostate cancer in HGPIN patients $(7.60 \%$ vs $23.1 \%, \mathbf{R R}=$ $0.39,95 \% \mathrm{CI}: 0.16-10.97, P \mathrm{P}=0.044)$, with moderate heterogeneity $\left(\mathrm{I}^{2}=47.9 \%, \chi^{2}\right.$ $=1.92, P=0.166)$. The adjusted indirect meta-analysis favored green tea catechins over other chemoprevention agents, and significantly when compared to natural food products combination ( $R R=0.355,95 \% C I$ : $0.134-0.934)$.

Conclusion: The overall efficacy of chemoprevention agents in HGPIN patients is limited. But Green tea catechins showed the superiority to decrease prostate cancer in HGPIN patients. 


\section{INTRODUCTION}

Prostate cancer is the second most common cancer and the fifth leading cause of cancer-related death in men worldwide [1]. It is urgent to develop effective chemoprevention agents that are expected to decrease prostate cancer risk, delay or prevent surgery or chemoradiotherapy, improve quality of life and decrease the frequency of invasive surveillance procedures $[2,3]$. High-grade prostatic intraepithelial neoplasia (HGPIN) is considered as the precursor or premalignant form of prostate cancer with cytological changes similar to those in invasive prostate $[2,3]$. HGPIN is diagnosed with atypical secretory luminal cells present by preexisting ducts and acini [4]. At least 30\% patients with a confirmed HGPIN will develop prostate cancer within 1 year $[5,6]$. Therefore, HGPIN patients are the appropriate at-risk population for chemoprevention strategies investigation.

The prostate cancer carcinogenesis is a complex process driven by genetic and epigenetic alterations $[7$, 8]. Hormonal imbalance and lifestyle-related factors are considered as the major contributors to prostate cancer [5, 9]. Regarding to hormonal imbalance, $5 \alpha$-dihydrotestosterone (DHT), androgen receptor (AR), female hormones estrogens are critical targets for prostate cancer chemopreventions [9-11]. 5- $\alpha$-reductase catalyzes the production of DHT. Then with increased androgenic activity, DHT activates multiple genes involved in carcinogenesis via AR [9-11]. Estrogen promoted the prostate cancer development by mediating estrogen receptors (ER) [12]. 5- $\alpha$-reductase inhibitor Dutasteride, Finasteride, AR antagonist Flutamide, Bicalutamide and ER blocker Toremifene are investigated as chemoprevention agents for prostate cancer in clinical trials [2, 3, 13-17]. Due to the anti-oxidant and antiproliferation activity and the limited toxicities, natural food compounds Selenium, Vitamin E, soy diets, tomato and green tea have been considered as the ideal candidate chemoprevention agents for prostate cancer in clinical trials [8, 18-23].

However, clinical trials performed with these agents in patients with HGPIN showed varied results. Most of these agents only showed minor effects to prevent prostate cancer development in HGPIN patients, for instance the Selenium and Vitamin E Cancer Prevention Trial (SELECT) [24, 25]. Even higher prostate cancer prevalence was found in HGPIN patients after taking some agents, for example Flutamid and the combination of lycopene, selenium, and green tea catechins [14, 26]. Moreover, it's important to find the agents with satisfying preventative efficiency to improve the clinical benefits for HGPIN patients. But due to the absence of head-to-head trials, network meta-analysis using direct and indirect evidence to compare the relative efficacy of these candidate agents is needed. In this study, We aimed to evaluate these chemoprevention agents and find the agents with the most satisfying efficiency.we performed a pairwise meta-analysis to summarize the efficacy of candidate chemoprevention agent, and used adjusted indirect meta-analysis to compare the relative efficacy of these candidate chemoprevention agents. We aimed to systematically summarize the efficacy of pharmacological agents and natural food compounds for HGPIN patients and find the agents with the most satisfying efficiency.

\section{RESULTS}

\section{Characteristics of included trials}

After removing duplicated literatures, unrelated literatures and some ineligible literatures, two investigators identified articles eligible for further review by screening titles and abstracts independently. Finally, we identified 13 literatures involved 3,020 patients eligible for analysis (Figure 1). Candidate chemoprevention agents used in these eligible studies included 5- $\alpha$ reductase inhibitor Dutasteride $(n=1)$, AR antagonist Flutamide $(n=1)$, Bicalutamide $(n=2)$, estrogen receptors blocker Toremifene $(n=2)$, micronutrient supplement Selenium $(n=1)$, green tea catechins $(n=2)$, Lycopene $(n=2)$, the natural food product combination $(n=2$, Lycopene + Selenium + green tea catechins and soy protein + Vitamin $\mathrm{E}+$ Selenium). The details about the thirteen literatures are listed in Table 1.

\section{Risk of bias}

No high risk of bias was assessed in these studies. The risk of bias evaluations for the included studies was summarized in Figure 2.

\section{Direct meta-analysis of the efficacy of chemoprevention agents for HGPIN}

The pooled prostate cancer incidence in HGPIN patients received chemoprevention agents and patients not received chemoprevention agents were $25.7 \%$ and $31.5 \%$ respectively. The overall incidence of prostate cancer in HGPIN was slightly decreased by chemoprevention agents (RR $=0.92,95 \%$ CI: $0.83-1.03, P=0.183$ ), with minor heterogeneity $\left(\mathrm{I}^{2}=22.3 \%, x^{2}=15.08, P=0.237\right)$, but without statistic significance (Figure 3). Begg's test and Egger's test both showed no evidence of substantial publication bias $(P=0.721, P=0.788)$. The funnel plot was shown in Figure 4.

Subgroup analysis showed that green tea catechins significantly decreased the prostate cancer in HGPIN patients $(7.60 \%$ vs $23.1 \%, \mathrm{RR}=0.39,95 \%$ CI: $0.16-10.97$, $P=0.044)$, with moderate heterogeneity $\left(\mathrm{I}^{2}=47.9 \%, x^{2}\right.$ 
$=1.92, P=0.166)$. Lycopene, Toremifene, Bicalutamide decreased the prostate cancer in HGPIN patients $(13.0 \%$ vs $19.2 \% \mathrm{RR}=0.70,95 \% \mathrm{CI}: 0.27-1.85,24.8 \%$ vs $32.0 \%$ $\mathrm{RR}=0.91,95 \%$ CI: $0.79-1.05,7.2 \%$ vs $14.3 \% \mathrm{RR}=0.42$, 95\% CI: $0.08-2.11$ respectively), but without statistical significances. The natural food combination showed slight increased prostate cancer in HGPIN patients $(7.60 \%$ vs $23.1 \%, \mathrm{RR}=1.11,95 \% \mathrm{CI}: 0.77-1.58)$ without statistical significance.

\section{Adjusted indirect meta-analysis of the efficacy of chemoprevention agents for HGPIN}

The network is given in Figure 5. We compared each pair of chemoprevention agents using placebo as a data bridge head-to-head. The indirect estimates favor green tea catechins over other chemoprevention agents, and significantly when compared to natural food products combination $(\mathrm{RR}=0.355,95 \% \mathrm{CI}$ : 0.134 , 0.934). Lycopene showed better chemoprevention effects in HGPIN patients than Dutasteride, natural food combination, Toremifene, Selenium and Flutamide, but without statistical significance. Regarding to the chemoprevention agents targeted on hormonal imbalance, the indirect estimates favor Bicalutamide over Dutasteride, Toremifene and Flutamide, but without statistical significance. Toremifene also showed better chemoprevention effects than Flutamide, but without statistical significance. All heterogeneity statistics are not significant at $P=0.05$.
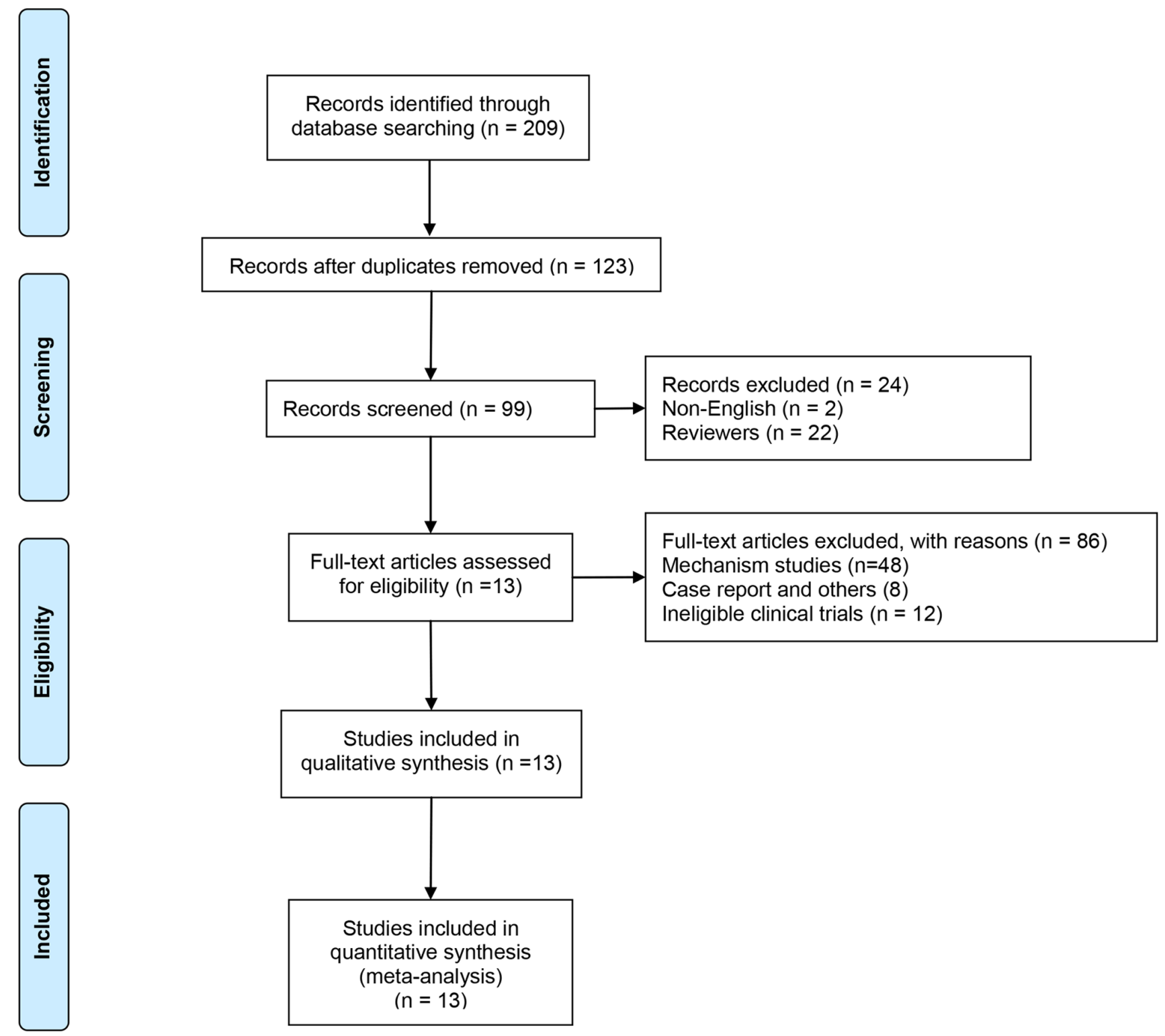

Figure 1: Flow diagram of study selection process. 
Table 1: Summary of clinical trials involved in the meta-analysis

\begin{tabular}{|c|c|c|c|c|c|c|c|c|c|}
\hline \multirow{2}{*}{ Authors } & \multirow{2}{*}{ Year } & \multirow{2}{*}{$\begin{array}{c}\text { Chemoprevent } \\
\text { Reagent }\end{array}$} & \multirow{2}{*}{ Dose } & \multirow{2}{*}{ Time } & \multirow{2}{*}{ Patient } & \multirow{2}{*}{ Race } & \multicolumn{2}{|c|}{ Prostate cancer } & \multirow{2}{*}{ Ref } \\
\hline & & & & & & & Treated & Control & \\
\hline Milonas & 2016 & Dutasteride & $50 \mathrm{mg} /$ day & 36 & HGPIN & Caucasian & $39 / 68$ & $52 / 83$ & 13 \\
\hline Kumar & 2015 & $\begin{array}{l}\text { Green tea } \\
\text { catechins }\end{array}$ & $\begin{array}{l}\text { EGCG } 400 \\
\mathrm{mg} / \text { day }\end{array}$ & 12 & $\begin{array}{l}\text { HGPIN/ } \\
\text { ASAP }\end{array}$ & $\begin{array}{l}\text { White \& } \\
\text { African } \\
\text { American }\end{array}$ & $5 / 49$ & $9 / 48$ & 8 \\
\hline Gontero & 2015 & $\begin{array}{l}\text { Natural food } \\
\text { product } \\
\text { combination }\end{array}$ & $\begin{array}{l}\text { lycopene } 35 \mathrm{mg}+ \\
\text { selenium } 55 \mathrm{mg}+ \\
\text { GTCs } 600 \mathrm{mg} / \text { day }\end{array}$ & 6 & $\begin{array}{l}\text { HGPIN/ } \\
\text { ASAP }\end{array}$ & & $10 / 27$ & $3 / 26$ & 25 \\
\hline Gann & 2015 & Lycopene & $30 \mathrm{mg} /$ day & 6 & HGPIN & $\begin{array}{l}\text { White \& } \\
\text { African } \\
\text { American }\end{array}$ & $4 / 26$ & $4 / 32$ & 20 \\
\hline Taneja & 2013 & Toremifene & $20 \mathrm{mg} /$ day & 36 & $\begin{array}{l}\text { HGPIN } \\
\text { /ASAP }\end{array}$ & $\begin{array}{l}\text { White \& } \\
\text { African } \\
\text { American }\end{array}$ & $229 / 709$ & $249 / 717$ & 15 \\
\hline Marshall & 2011 & Selenium & $200 \mathrm{mg} /$ day & 36 & HGPIN & $\begin{array}{l}\text { White \& } \\
\text { African } \\
\text { American }\end{array}$ & $48 / 135$ & $49 / 134$ & 25 \\
\hline Fleshner & 2011 & $\begin{array}{l}\text { Natural food } \\
\text { product } \\
\text { combination }\end{array}$ & $\begin{array}{l}\text { Soy protein } 40 \mathrm{~g}+ \\
\text { vitamin E } 800 \mathrm{U}+ \\
\text { selenium } \\
200 \mathrm{~g} / \text { day }\end{array}$ & 36 & HGPIN & -- & $41 / 156$ & $39 / 147$ & 24 \\
\hline Zanardi & 2009 & Bicalutamide & 50 or $100 \mathrm{mg} /$ week & 6 & HGPIN & -- & $1 / 8$ & $3 / 6$ & 16 \\
\hline Bono & 2007 & Bicalutamide & $50 \mathrm{mg} /$ day & 6 & & -- & $1 / 20$ & $1 / 22$ & 17 \\
\hline Mohanty & 2007 & Lycopene & $8 \mathrm{mg} /$ day & 12 & & -- & $2 / 20$ & $6 / 20$ & 21 \\
\hline Price & 2006 & Toremifene & $20-60 \mathrm{mg} /$ day & 12 & HGPIN & $\begin{array}{l}\text { White \& } \\
\text { African } \\
\text { American }\end{array}$ & $31 / 109$ & $15 / 308$ & 3 \\
\hline Bettuzzi & 2006 & $\begin{array}{l}\text { Green tea } \\
\text { catechins }\end{array}$ & $600 \mathrm{mg} /$ day & 12 & HGPIN & $\begin{array}{l}\text { White \& } \\
\text { African } \\
\text { American }\end{array}$ & $1 / 30$ & $9 / 30$ & 5 \\
\hline Alberts & 2006 & Flutamide & $250 \mathrm{mg} /$ day & 12 & HGPIN & -- & $4 / 30$ & $3 / 30$ & 14 \\
\hline
\end{tabular}

Table 2: Indirect comparison of chemoprevention agents under fixed effects

\begin{tabular}{|c|c|c|c|c|c|c|c|c|}
\hline & Dutasteride & $\begin{array}{l}\text { Green tea } \\
\text { catechins }\end{array}$ & $\begin{array}{l}\text { Natural food } \\
\text { combination }\end{array}$ & Lycopene & Toremifene & Selenium & Flutamide & Bicalutamide \\
\hline Dutasteride & 1 & $\begin{array}{c}2.33 \\
(0.91,6.00)\end{array}$ & $\begin{array}{c}0.83 \\
(0.53,1.29)\end{array}$ & $\begin{array}{c}1.31 \\
(0.48,3.57)\end{array}$ & $\begin{array}{c}1.00 \\
(0.74,1.36)\end{array}$ & $\begin{array}{c}0.94 \\
(0.50,1.76)\end{array}$ & $\begin{array}{c}0.69 \\
(0.16,2.88)\end{array}$ & $\begin{array}{c}0.06 \\
(0.42,10.1)\end{array}$ \\
\hline $\begin{array}{l}\text { Green tea } \\
\text { catechins }\end{array}$ & $\begin{array}{c}0.43 \\
(0.17,1.10)\end{array}$ & $(0.7,0.00)$ & $\begin{array}{c}0.35 \\
(0.13,0.94)^{*}\end{array}$ & $\begin{array}{c}0.65 \\
(0.23,1.86)\end{array}$ & $\begin{array}{c}0.43 \\
(0.17,1.08)\end{array}$ & $\begin{array}{c}0.40 \\
(0.14,1.18)\end{array}$ & $\begin{array}{c}0.30 \\
(0.06,1.57)\end{array}$ & $\begin{array}{c}0.88 \\
(0.15,5.39)\end{array}$ \\
\hline $\begin{array}{l}\text { Natural food } \\
\text { combination }\end{array}$ & $\begin{array}{c}1.21 \\
(0.77,1.88)\end{array}$ & $\begin{array}{c}2.82 \\
(1.06,0.47)^{*}\end{array}$ & 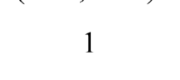 & $\begin{array}{c}1.47 \\
(0.52,4,12)\end{array}$ & $\begin{array}{c}1.21 \\
(0.83,1.78)\end{array}$ & $\begin{array}{c}1.14 \\
(0.58,2.23)\end{array}$ & $\begin{array}{c}0.83 \\
(0.19,3.55)\end{array}$ & $\begin{array}{c}2.32 \\
(0.4711 .5)\end{array}$ \\
\hline Lycopene & $\begin{array}{c}0.77 \\
(0.28,2.09)\end{array}$ & $\begin{array}{c}1.78 \\
(0.47,6.73)\end{array}$ & $\begin{array}{c}0.63 \\
(0.23,1.78)\end{array}$ & 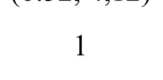 & $\begin{array}{c}0.77 \\
(0.29,2.05)\end{array}$ & $\begin{array}{c}0.72 \\
(0.23,2.22)\end{array}$ & $\begin{array}{c}0.53 \\
(0.10,3.55)\end{array}$ & $\begin{array}{c}1.58 \\
(0.25,9.92)\end{array}$ \\
\hline Toremifene & $\begin{array}{c}1.00 \\
(0.74,1.34)\end{array}$ & $\begin{array}{c}2.32 \\
(0.93,5.82)\end{array}$ & $\begin{array}{c}0.83 \\
(0.56,1.21)\end{array}$ & $\begin{array}{c}1.30 \\
(0.49,3.47)\end{array}$ & $(0.25,2.00)$ & $\begin{array}{c}0.94 \\
(0.52,1.69)\end{array}$ & $\begin{array}{c}0.68 \\
(0.17,2.82)\end{array}$ & $\begin{array}{c}2.05 \\
(0.41,11.6)\end{array}$ \\
\hline Selenium & $\begin{array}{c}1.06 \\
(0.57,1.99)\end{array}$ & $\begin{array}{c}2.48 \\
(0.85,7.23)\end{array}$ & $\begin{array}{c}0.88 \\
(0.45,1.72)\end{array}$ & $\begin{array}{c}1.39 \\
(0.45,4.27)\end{array}$ & $\begin{array}{c}1.07 \\
(0.59,1.92)\end{array}$ & 1 & $\begin{array}{c}0.73 \\
(0.16,3.33)\end{array}$ & $\begin{array}{c}2.19 \\
(0.41,11.6)\end{array}$ \\
\hline Flutamide & $\begin{array}{c}1.46 \\
(0.35,6.11)\end{array}$ & $\begin{array}{c}3.40 \\
(0.64,18.1)\end{array}$ & $\begin{array}{c}1.21 \\
(0.28,5.16)\end{array}$ & $\begin{array}{c}1.90 \\
(0.34,10.5)\end{array}$ & $\begin{array}{c}1.43 \\
(0.35,5.91)\end{array}$ & $\begin{array}{c}1.37 \\
(0.30,6.27)\end{array}$ & $(0, x, 0,00)$ & $\begin{array}{c}2.99 \\
(0.37,24.6)\end{array}$ \\
\hline Bicalutamide & $\begin{array}{c}0.49 \\
(0.10,2.37)\end{array}$ & $\begin{array}{c}1.13 \\
(0.19,6.91)\end{array}$ & $\begin{array}{c}0.40 \\
(0.08,2.00)\end{array}$ & $\begin{array}{c}0.64 \\
(0.10,4.00)\end{array}$ & $\begin{array}{c}0.49 \\
(0.10,2.35)\end{array}$ & $\begin{array}{c}0.46 \\
(0.09,2.42)\end{array}$ & $\begin{array}{c}0.33 \\
(0.04,2.74)\end{array}$ & $(0,0,-1 . .0)$ \\
\hline
\end{tabular}




\section{DISCUSSION}

In this systematic review, we combined direct evidence from 13 randomized controlled trials comparing 7 different interventions and reporting on 3,020 participants with HGPIN to make observations regarding the potential efficacy of prostate cancer chemoprevention agents. The meta-analysis showed that the efficacy of prostate cancer chemoprevention agents is not satisfying, it only slightly decreased the prostate cancer and without significance. However, compared to other agents, green tea catechins showed promising benefits for HGPIN patients, and significantly better than the natural food product combination.

Our study extends findings from primary randomized controlled trials and systematic reviews. Most of the study for prostate cancer prevention focused on the observation or retrospective study to investigate the risk factors for prostate cancer, or the effects of candidate agents to prevent prostate cancer progression, recurrence and mortality. Chemoprevention agents targeted on pre-cancer patients to decrease prostate cancer risk is also important to improve the health outcomes. An ideal preventive agent should delay or reverse carcinogenesis effectively,

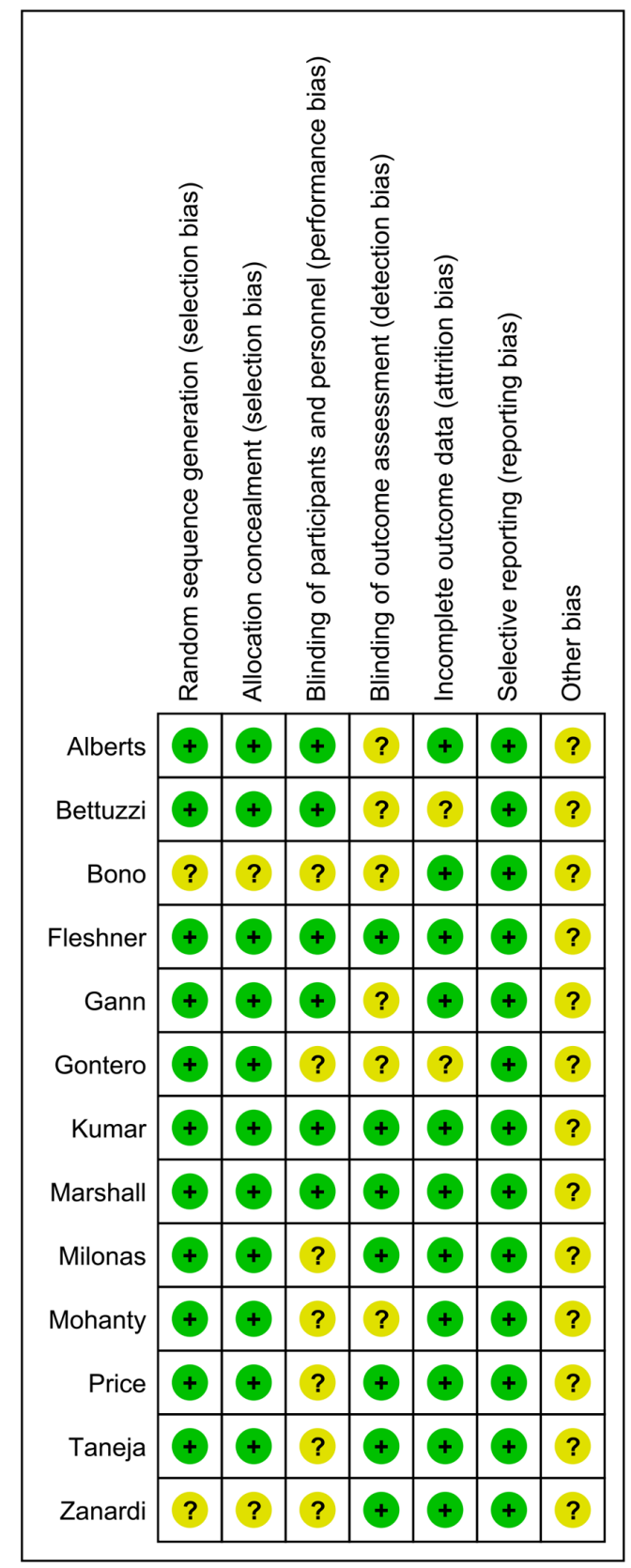

Figure 2: Risk of bias evaluations. 


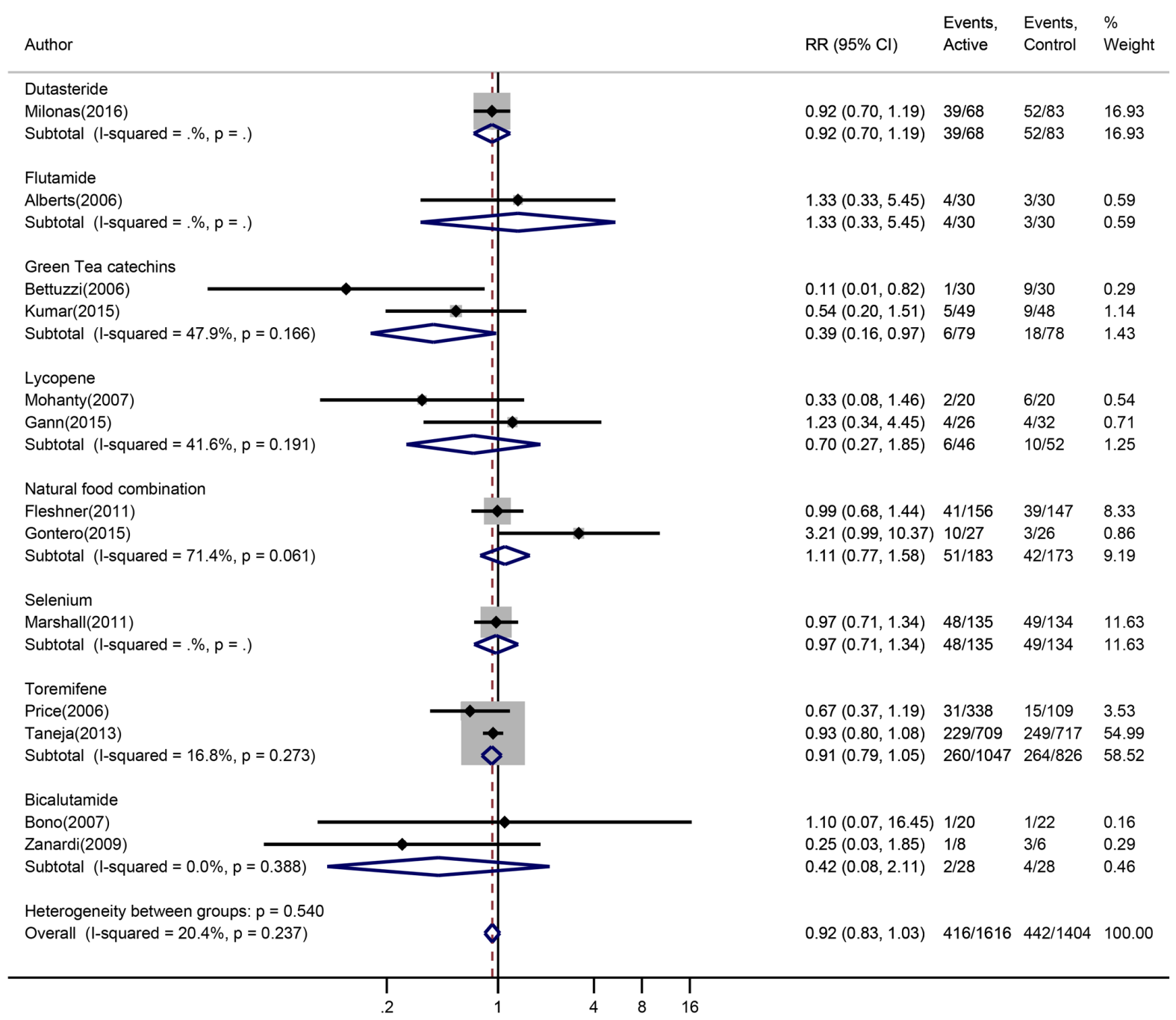

Figure 3: Forest plot for risk ratio confidence intervals of prostate cancer incidence in HGPIN patients. The red squares indicated the single risk ratios reported from each study. The black diamond squares indicated the pooled risk ratios from meta-analysis.

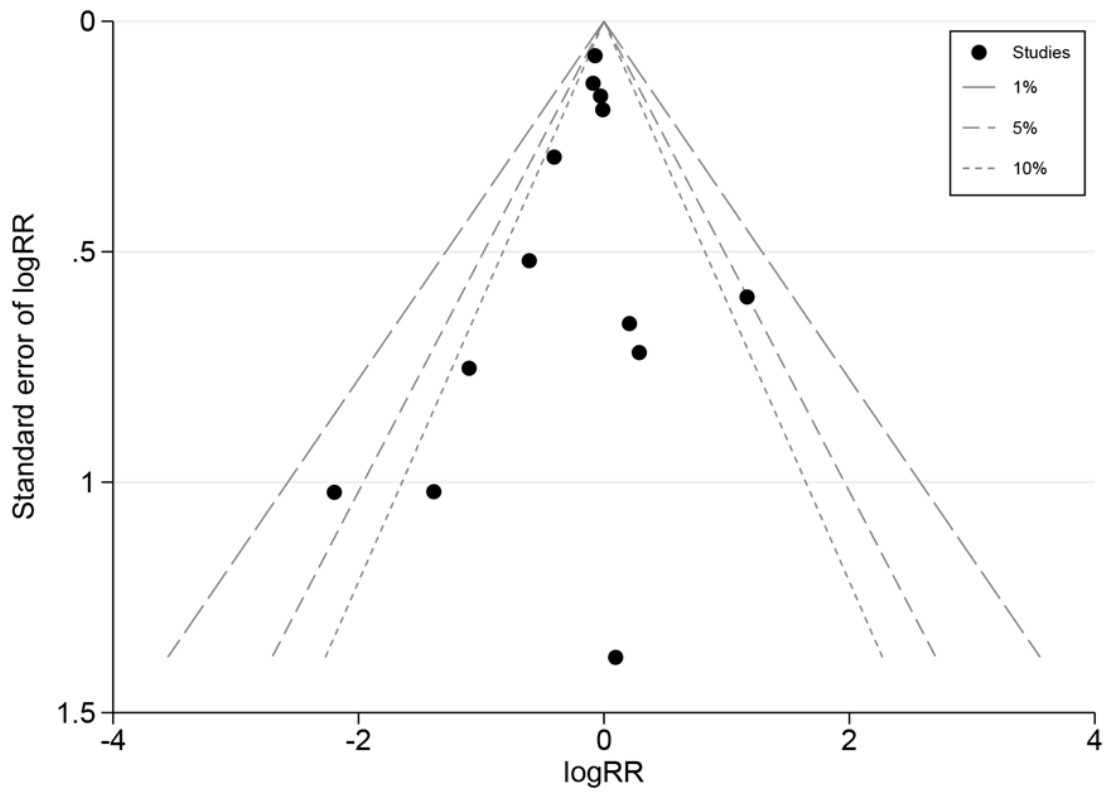

Figure 4: Funnel plot. 
at the same time, it should not cause any harm to healthy people, which raised the bar for chemoprevention research. Former studies showed that some 5- $\alpha$ reductase inhibitor showed significant effects to reduce the risk of prostate cancer, but with increased risk for highgrade disease [27-29]. For another, HGPIN patients are at high risk to develop prostate cancer $[5,6]$, but these studies are performed on general risk population but not HGPIN patients. Clinical trials to investigate these agents and develop novel chemoprevention agents in HGPIN population were needed. In this study, we summarized the findings from primary randomized controlled trials to get a more clear data about chemoprevention of prostate cancer in HGPIN patients.

The chemoprevention agents summarized in this study are targeted on hormonal imbalance or diets, the two important contributors to prostate cancer [5, 9]. Agents targeted on hormonal imbalance summarized in this study include Dutasteride [13], Flutamide [14], Bicalutamide $[16,17]$ and Toremifene $[3,15]$. The Dutasteride clinical trial involved in this study showed that Dutasteride did not decrease prostate cancer incidence but did not worsen the HGPIN [13]. In the Flutamide trial, no evidence of benefit was found [14]. The pooled results from metaanalysis showed the potential of Bicalutamide to inhibit prostate cancer development, but without significance [16, 17]. The pooled efficacy of Toremifene was also limited in HGPIN patients $[3,15]$. However, the adjusted indirect analysis showed that Bicalutamide might have better clinical benefits for HGPIN patients than Dutasteride, Toremifene and Flutamide. This result might be related to the different mechanisms among these drugs. Bicalutamide and Flutamide are AR antagonists. AR plays a pivotal role in prostate cancer by transactivation of multiple genes involved in tumorigenesis [30]. Moreover, Bicalutamide was derived from flutamide by structural modification to increase the agonist properties against AR [31]. However, the limitation of these chemical drugs underscored the needs of other chemopreventive agents for HGPIN patients.

Natural products such as vitamins, minerals, probiotics, herbal medicines showed potential cancer prevention effects with low toxicity profiles [32, 33]. "Food-based" prevention approaches such as green tea, soy product, lycopene, selenium included in this metaanalysis are all reported to be associated with reduced risk of cancer. In our direct meta-analysis, subgroup analysis showed that only green tea catechins showed significant clinical benefits for HGPIN patients. In our indirect meta-analysis, the results favor green tea catechins over all other chemoprevention agents. Observation studies in Japan and China showed that green tea intake in diet might decrease the risk of localized and advanced prostate cancers [34-36]. But some studies showed no association between tea consumption and prostate cancer risk [37, 38]. A recent meta-analysis did not support the conclusion that tea consumption could reduce prostate cancer risk neither [39]. The data used in this meta-analysis were extracted from cohort studies and case-control studies, but not randomized controlled trials. When they limited the analysis to case-control study, they found a protective effect for tea consumption against prostate cancer. Our

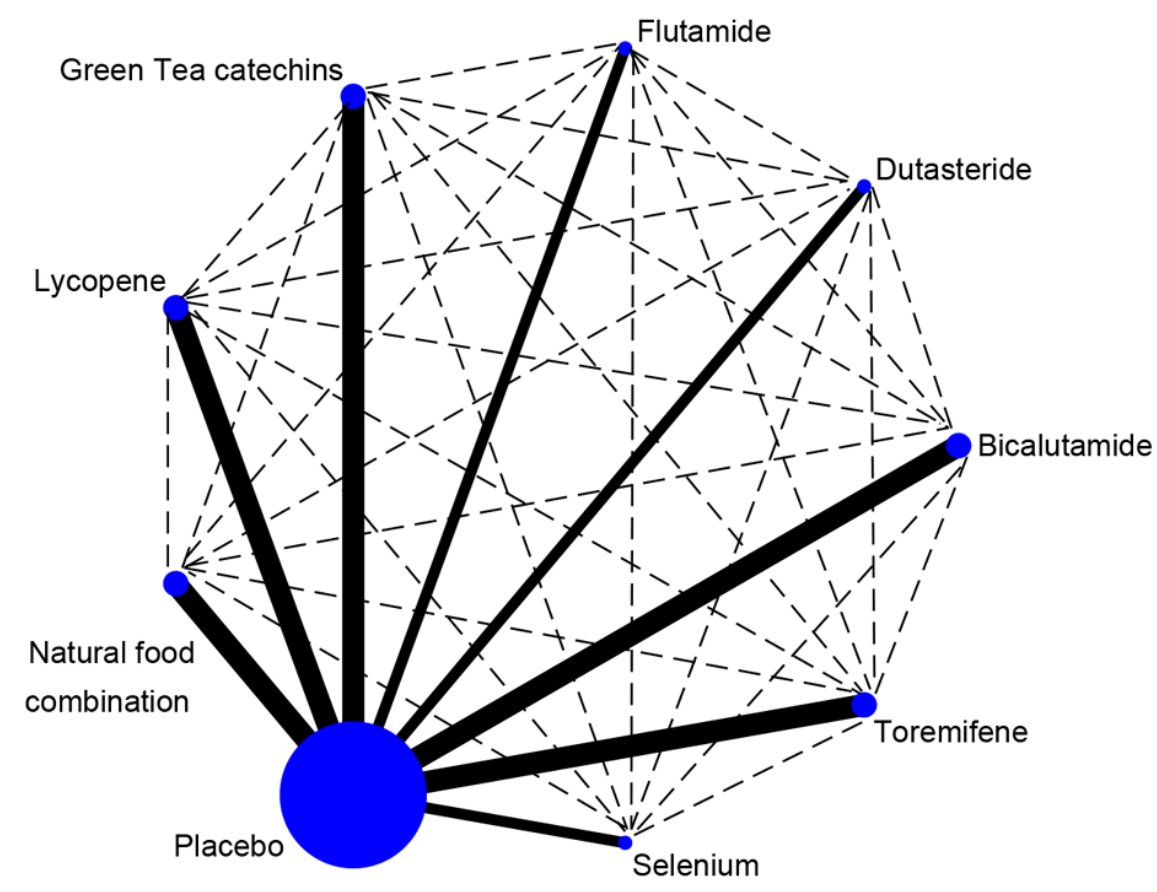

Figure 5: The network in the adjusted indirect analysis. The full line indicates the direct analysis and the dotted line indicates the indirect analysis. 
results pooled results from randomized controlled trials supported the conclusion that green tea catechins was an efficient agent for HGPIN patients to prevent prostate cancer. (-)-epigallocatechin-3-gallate (EGCG) are the most abundant green tea catechins, comprising 50\% to $75 \%$ of the material in the investigational agent in the two trials $[5,8]$. EGCG showed anticancer activity for prostate cancer in cell model, animals and human clinical trials $[5,8,40]$. EGCG can decreased androgen receptor (AR) and inhibit 5-a-reductase. It also showed the effects to inhibit proliferation, angiogenesis, apoptotic cell death and other cell activity through oncogenic signaling pathway such as NFKB/MAPK/IGFR/COX-2 [40]. Since carcinogenesis is a process with multiple stages and multiple factors involved, the synergistic effects of EGCG may contribute to the superior benefits of EGCG than other chemoprevention agents.

Our adjusted indirect meta-analysis showed that lycopene might have better chemoprevention effects in HGPIN patients than most of the other agents except green tea catechins and Bicalutamide, but without significance. Lycopene has been studies for a long time because of their efficacy to lower the risk of prostate cancer [41]. Between the two lycopene trials in this meta-analysis, the HGPIN patients were given the different dose, at $8 \mathrm{mg} /$ day in Mohanty's study and 30mg/day in Gann's study $[20,21]$. But the lower dose showed the better clinical benefit. In the two natural production combination trails, each single components all have the potential to prevent prostate cancer, but the combination even worsen the prostate cancer incidence $[24,26]$. The failure of high dose lycopene and the combination in Gontere's study may due to the short time intervention, only 6 months. We performed a subgroup Meta-analysis to compare trials with 6 months intervention and that with more than 6 month, and found no significant difference between them (Supplemental Figure 1). But this subgroup setting is not thorough due to the limited biological significance. Recent data showed that a high prostate cancer detection rate at early repeat biopsy (6 months) in men with HGPIN is common in several clinical trials, because prostate cancer has been already present at the initial HGPIN diagnosis [13]. This may help to explain the reason why 6 month intervention showed limited chemoprevention effects. Larger, longer and précised design trials are needed to figure out the reason.

There are limitations in this study. A recent study to systematically summarize dietary, nutritional, and physical activity interventions for the prevention of prostate cancer progression and mortality failed to get a conclusion. The author considered limitation patients numbers, risk of bias, underpowered, inadequately reported, short duration or measured surrogate outcomes of unproven relationship to mortality or disease progression as the potential reasons [42]. These issues may be common in modification interventions. Although we didn't find significant risk bias in the analysis, the above reasons may exist. HGPIN may be more prevalent in African American men even after controlling other factors [43]. However most of the patients recruited in these trials are white men. Prostate cancer incidence was significantly higher in plurifocal HGPIN patients than monofocal HGPIN patients [44]. The number of core samples with HGPIN increase is in parallel with the risk for prostate cancer [45]. Over diagnosis of HGPIN influenced the results from the clinical trials taking candidate agents to prevent development of prostate cancer [46]. However in this meta-analysis, we didn't analysis the race, histopathology status, the number of core samples and the over diagnosis issues about HGPIN, which are potential to cause the bias of the results. Due to the limited data, we only assess the prostate cancer incidence but not other indicators such as the disease free survival, the PSA changes, and adverse effects as additional endpoint.

In conclusion, this study didn't show a significant effect of the chemoprevention agents to prevent prostate cancer development in HGPIN patients. The direct and indirect meta-analysis demonstrated that green tea green tea catechins significantly inhibit prostate cancer in HGPIN patients and are better than other chemoprevention agents for prostate cancer. The results of this study have implication for the prostate cancer prevention and support the future clinical study with green tea catechins for HGPIN patients.

\section{MATERIALS AND METHODS}

\section{Search strategy and searches}

Literature searches were conducted in PubMed, EMBASE and Cochrane library according to Cochrane guidelines before January $31^{\text {st }}, 2017$ [47]. Search key terms included high-grade prostatic intraepithelial neoplasia, chemoprevention, prostate cancer and randomized controlled trial. We also manually searched references in identified studies in case of missing trials.

\section{Study selection}

Randomized controlled trials that enrolled highgrade prostatic intraepithelial neoplasia patients to receive any intervention for prostate cancer chemoprevention were included. The primary outcome assessed in this study is the prevalence of prostate cancer in highgrade prostatic intraepithelial neoplasia patient after chemoprevention intervention. The eligible studies should report the incidence of prostate cancer development after the intervention. The risk of bias was assessed by three reviewers using the Cochrane Collaboration's tool [48]. The risk of bias was graded as high, low, or unclear. 


\section{Statistical method}

Direct meta-analysis was performed with fixed effects model to estimate pooled relative ratios and $95 \%$ confidence intervals incorporating heterogeneity within and between studies. Subgroup analysis was based on the different chemoprevention agents. Statistical heterogeneity was assessed with $\mathrm{I}^{2}$ statistic, with values over 50\% indicating substantial heterogeneity. Publication bias was analyzed by both Begg's and Egger's regression asymmetry test, and visually evaluated using the funnel plot.

Adjusted indirect comparisons were performed to estimate the relative ratio between different candidate chemoprevention agents using placebo as a data bridge. The adjusted indirect meta-analysis developed by Bucher et al. allows for the comparison of two treatments by comparing each of the interventions with a common comparator [49]. The "indirect" command implemented in Stata was employed to convert the summary estimates (log RRs) and measures of uncertainty (variances) from the meta-analyses into an RR and 95\% CI representing the difference between each two chemoprevention agents [50]. Stata Statistical Software (version 14.0 Stata Corp., College Station, TX, USA) was used for all analyses. A two-sided $\mathrm{P}$ value $\leq 0.05$ was considered as statistically significant. The data set and command used in Stata are list in Supplemental Table 1.

\section{Abbreviations}

HGPIN, High-Grade Prostatic Intraepithelial Neoplasia; RR, risk ratio; CI, confidence interval; DHT, $5 \alpha$-dihydrotestosterone; AR, androgen receptor; PSA, Prostate-specific antigen.

\section{Author contributions}

K.C. and X.N. collected data, analyzed data and draft the manuscript, Y.D. analyzed data and mainly drafted the manuscript. X.T. assisted the data analysis. S.A. assisted the data analysis and manuscript. Y.G. and Y.X. assisted the data collection. H.X. assisted the data analysis. Y.Z. assisted manuscript. W.M. and T.Z. designed the study and supervised the manuscript.

\section{CONFLICTS OF INTEREST}

The authors declared no conflicts of interests.

\section{FUNDING}

This work was supported by National Natural Science Foundation of China (Grant No. 31570917 and 31400752).

\section{REFERENCES}

1. Torre LA, Bray F, Siegel RL, Ferlay J, Lortet-Tieulent J, Jemal A. Global cancer statistics, 2012. CA Cancer J Clin. 2015; 65:87-108.

2. Thompson IM, Lucia MS, Redman MW, Darke A, La Rosa FG, Parnes HL, Lippman SM, Coltman CA. Finasteride decreases the risk of prostatic intraepithelial neoplasia. J Urol. 2007; 178:107-09.

3. Price D, Stein B, Sieber P, Tutrone R, Bailen J, Goluboff E, Burzon D, Bostwick D, Steiner M. Toremifene for the prevention of prostate cancer in men with high grade prostatic intraepithelial neoplasia: results of a double-blind, placebo controlled, phase IIB clinical trial. J Urol. 2006; 176:965-70; discussion 970-1.

4. De Marzo AM, Haffner MC, Lotan TL, Yegnasubramanian S, Nelson WG. Premalignancy in Prostate Cancer: Rethinking What we Know. Cancer Prev Res (Phila). 2016; 9:648-56.

5. Bettuzzi S, Brausi M, Rizzi F, Castagnetti G, Peracchia G, Corti A. Chemoprevention of human prostate cancer by oral administration of green tea catechins in volunteers with high-grade prostate intraepithelial neoplasia: a preliminary report from a one-year proof-of-principle study. Cancer Res. 2006; 66:1234-40.

6. Paltsev M, Kiselev V, Drukh V, Muyzhnek E, Kuznetsov I, Andrianova E, Baranovskiy P. First results of the doubleblind randomized placebo-controlled multicenter clinical trial of DIM-based therapy designed as personalized approach to reverse prostatic intraepithelial neoplasia (PIN). EPMA J. 2016; 7:5.

7. Lippman SM, Hong WK. Cancer prevention science and practice. Cancer Res. 2002; 62:5119-25.

8. Kumar NB, Pow-Sang J, Egan KM, Spiess PE, Dickinson S, Salup R, Helal M, McLarty J, Williams CR, Schreiber F, Parnes HL, Sebti S, Kazi A, et al. Randomized, PlaceboControlled Trial of Green Tea Catechins for Prostate Cancer Prevention. Cancer Prev Res (Phila). 2015; 8:879-87.

9. Heinlein CA, Chang C. Androgen receptor in prostate cancer. Endocr Rev. 2004; 25:276-308.

10. Farnsworth WE. Roles of estrogen and SHBG in prostate physiology. Prostate. 1996; 28:17-23.

11. Kosaka T, Miyajima A, Oya M. Is DHT Production by $5 \alpha$-Reductase Friend or Foe in Prostate Cancer? Front Oncol. 2014; 4:247.

12. Lau KM, To KF. Importance of Estrogenic Signaling and Its Mediated Receptors in Prostate Cancer. Int J Mol Sci. 2016; $17: 17$.

13. Milonas D, Auskalnis S, Skulcius G, Gudinaviciene I, Jievaltas M, Joniau S. Dutasteride for the prevention of prostate cancer in men with high-grade prostatic intraepithelial neoplasia: results of a phase III randomized open-label 3-year trial. World J Urol. 2017; 35:721-728.

14. Alberts SR, Novotny PJ, Sloan JA, Danella J, Bostwick 
DG, Sebo TJ, Blute ML, Fitch TR, Levitt R, Lieberman $\mathrm{R}$, Loprinzi CL. Flutamide in men with prostatic intraepithelial neoplasia: a randomized, placebo-controlled chemoprevention trial. Am J Ther. 2006; 13:291-97.

15. Taneja SS, Morton R, Barnette G, Sieber P, Hancock ML, Steiner M. Prostate cancer diagnosis among men with isolated high-grade intraepithelial neoplasia enrolled onto a 3 -year prospective phase III clinical trial of oral toremifene. J Clin Oncol. 2013; 31:523-29.

16. Zanardi S, Puntoni M, Maffezzini M, Bandelloni R, Mori M, Argusti A, Campodonico F, Turbino L, Branchi D, Montironi R, Decensi A. Phase I-II trial of weekly bicalutamide in men with elevated prostate-specific antigen and negative prostate biopsies. Cancer Prev Res (Phila). 2009; 2:377-84.

17. Bono AV, Mazzucchelli R, Ferrari I, Lopez-Beltran A, Galosi AB, Cheng L, Montironi R. Bicalutamide $50 \mathrm{mg}$ monotherapy in patients with isolated high-grade PIN: findings in repeat biopsies at 6 months. J Clin Pathol. 2007; 60:443-46.

18. Van Patten CL, de Boer JG, Tomlinson Guns ES. Diet and dietary supplement intervention trials for the prevention of prostate cancer recurrence: a review of the randomized controlled trial evidence. J Urol. 2008; 180:2314-21; discussion 2721-2.

19. Tan HL, Thomas-Ahner JM, Grainger EM, Wan L, Francis DM, Schwartz SJ, Erdman JW Jr, Clinton SK. Tomatobased food products for prostate cancer prevention: what have we learned? Cancer Metastasis Rev. 2010; 29:553-68.

20. Gann PH, Deaton RJ, Rueter EE, van Breemen RB, Nonn L, Macias V, Han M, Ananthanarayanan V. A Phase II Randomized Trial of Lycopene-Rich Tomato Extract Among Men with High-Grade Prostatic Intraepithelial Neoplasia. Nutr Cancer. 2015; 67:1104-12.

21. Mohanty NK, Saxena S, Singh UP, Goyal NK, Arora RP. Lycopene as a chemopreventive agent in the treatment of high-grade prostate intraepithelial neoplasia. Urol Oncol. 2005; 23:383-85.

22. Clark LC, Combs GF Jr, Turnbull BW, Slate EH, Chalker DK, Chow J, Davis LS, Glover RA, Graham GF, Gross EG, Krongrad A, Lesher JL Jr, Park HK, et al. Effects of selenium supplementation for cancer prevention in patients with carcinoma of the skin. A randomized controlled trial. JAMA. 1996; 276:1957-63.

23. Lippman SM, Klein EA, Goodman PJ, Lucia MS, Thompson IM, Ford LG, Parnes HL, Minasian LM, Gaziano JM, Hartline JA, Parsons JK, Bearden JD 3rd, Crawford ED, et al. Effect of selenium and vitamin $\mathrm{E}$ on risk of prostate cancer and other cancers: the Selenium and Vitamin E Cancer Prevention Trial (SELECT). JAMA. 2009; 301:39-51.

24. Fleshner NE, Kapusta L, Donnelly B, Tanguay S, Chin J, Hersey K, Farley A, Jansz K, Siemens DR, Trpkov K, Lacombe L, Gleave M, Tu D, Parulekar WR. Progression from high-grade prostatic intraepithelial neoplasia to cancer: a randomized trial of combination vitamin-E, soy, and selenium. J Clin Oncol. 2011; 29:2386-90.

25. Marshall JR, Tangen CM, Sakr WA, Wood DP Jr, Berry DL, Klein EA, Lippman SM, Parnes HL, Alberts DS, Jarrard DF, Lee WR, Gaziano JM, Crawford ED, et al. Phase III trial of selenium to prevent prostate cancer in men with high-grade prostatic intraepithelial neoplasia: SWOG S9917. Cancer Prev Res (Phila). 2011; 4:1761-69.

26. Gontero P, Marra G, Soria F, Oderda M, Zitella A, Baratta F, Chiorino G, Gregnanin I, Daniele L, Cattel L, Frea B, Brusa P. A randomized double-blind placebo controlled phase I-II study on clinical and molecular effects of dietary supplements in men with precancerous prostatic lesions. Chemoprevention or "chemopromotion"? Prostate. 2015; 75:1177-86.

27. Thompson IM, Goodman PJ, Tangen CM, Lucia MS, Miller GJ, Ford LG, Lieber MM, Cespedes RD, Atkins JN, Lippman SM, Carlin SM, Ryan A, Szczepanek CM, et al. The influence of finasteride on the development of prostate cancer. N Engl J Med. 2003; 349:215-24.

28. Andriole GL, Bostwick DG, Brawley OW, Gomella LG, Marberger M, Montorsi F, Pettaway CA, Tammela TL, Teloken C, Tindall DJ, Somerville MC, Wilson TH, Fowler IL, et al. Effect of dutasteride on the risk of prostate cancer. N Engl J Med. 2010; 362:1192-202.

29. Hamilton RJ, Kahwati LC, Kinsinger LS. Knowledge and use of finasteride for the prevention of prostate cancer. Cancer Epidemiol Biomarkers Prev. 2010; 19:2164-71.

30. Cai C, He HH, Chen S, Coleman I, Wang H, Fang Z, Chen S, Nelson PS, Liu XS, Brown M, Balk SP. Androgen receptor gene expression in prostate cancer is directly suppressed by the androgen receptor through recruitment of lysine-specific demethylase 1. Cancer Cell. 2011; 20:45771.

31. Chen Y, Clegg NJ, Scher HI. Anti-androgens and androgendepleting therapies in prostate cancer: new agents for an established target. Lancet Oncol. 2009; 10:981-91.

32. Crowell JA. The chemopreventive agent development research program in the Division of Cancer Prevention of the US National Cancer Institute: an overview. Eur J Cancer. 2005; 41:1889-910.

33. Greenlee H. Natural products for cancer prevention. Semin Oncol Nurs. 2012; 28:29-44.

34. Sawada N. Risk and preventive factors for prostate cancer in Japan: The Japan Public Health Center-based prospective (JPHC) study. J Epidemiol. 2017; 27:2-7.

35. Jian L, Xie LP, Lee AH, Binns CW. Protective effect of green tea against prostate cancer: a case-control study in southeast China. Int J Cancer. 2004; 108:130-35.

36. Kurahashi N, Sasazuki S, Iwasaki M, Inoue M, Tsugane S; JPHC Study Group. Green tea consumption and prostate cancer risk in Japanese men: a prospective study. Am J Epidemiol. 2008; 167:71-77. 
37. Ellison LF. Tea and other beverage consumption and prostate cancer risk: a Canadian retrospective cohort study. Eur J Cancer Prev. 2000; 9:125-30.

38. Kikuchi N, Ohmori K, Shimazu T, Nakaya N, Kuriyama S, Nishino Y, Tsubono Y, Tsuji I. No association between green tea and prostate cancer risk in Japanese men: the Ohsaki Cohort Study. Br J Cancer. 2006; 95:371-73.

39. Lin YW, Hu ZH, Wang X, Mao QQ, Qin J, Zheng XY, Xie LP. Tea consumption and prostate cancer: an updated metaanalysis. World J Surg Oncol. 2014; 12:38.

40. Khan N, Mukhtar H. Modulation of signaling pathways in prostate cancer by green tea polyphenols. Biochem Pharmacol. 2013; 85:667-72.

41. Ilic D, Forbes KM, Hassed C. Lycopene for the prevention of prostate cancer. Cochrane Database Syst Rev. 2011; :CD008007.

42. Hackshaw-McGeagh LE, Perry RE, Leach VA, Qandil S, Jeffreys M, Martin RM, Lane JA. A systematic review of dietary, nutritional, and physical activity interventions for the prevention of prostate cancer progression and mortality. Cancer Causes Control. 2015; 26:1521-50.

43. Kumar NB, Pow-Sang JM, Spiess PE, Park JY, Chornokur G, Leone AR, Phelan CM. Chemoprevention in African American Men With Prostate Cancer. Cancer Control. 2016; 23:415-423.

44. Roscigno M, Scattoni V, Freschi M, Raber M, Colombo R, Bertini R, Montorsi F, Rigatti P. Monofocal and plurifocal high-grade prostatic intraepithelial neoplasia on extended prostate biopsies: factors predicting cancer detection on extended repeat biopsy. Urology. 2004; 63:1105-10.
45. Kronz JD, Allan CH, Shaikh AA, Epstein JI. Predicting cancer following a diagnosis of high-grade prostatic intraepithelial neoplasia on needle biopsy: data on men with more than one follow-up biopsy. Am J Surg Pathol. 2001; 25:1079-85.

46. Zynger DL, Yang X. High-grade prostatic intraepithelial neoplasia of the prostate: the precursor lesion of prostate cancer. Int J Clin Exp Pathol. 2009; 2:327-38.

47. Higgins JP. Cochrane handbook for Systematic Reviews of intervention Cochrane handbook for Systematic Reviews of intervention. The Cochrane Library Chichester. John Wiley \& Sons, Ltd; 2006.

48. Higgins JP, Altman DG, Gøtzsche PC, Jüni P, Moher D, Oxman AD, Savovic J, Schulz KF, Weeks L, Sterne JA; Cochrane Bias Methods Group; Cochrane Statistical Methods Group. The Cochrane Collaboration's tool for assessing risk of bias in randomised trials. BMJ. 2011; 343:d5928.

49. Bucher HC, Guyatt GH, Griffith LE, Walter SD. The results of direct and indirect treatment comparisons in metaanalysis of randomized controlled trials. J Clin Epidemiol. 1997; 50:683-91.

50. Miladinovic B, Chaimani A, Hozo I, Djulbegovic B. Indirect treatment comparison. Stata J. 2014; 14:11. 